\title{
GIS Based Landslide Sensitivity Analysis of Babadağ District (Denizli/Turkey) Landslide Areas
}

\author{
Prof. Dr. Mehmet Ali Özdemir
}

ORCID ID: https://orcid.org/0000-0003-2095-5683

Afyon Kocatepe University, Faculty of Arts and Sciences, Department of Geography, Afyonkarahisar - TURKEY

Oğuzhan Çırak

ORCID ID: https://orcid.org/0000-0002-3309-6948

PhD Student / Afyon Kocatepe Üniversitesi, Institute of Social Sciences, Department of Geography, Afyonkarahisar - TURKEY

\author{
Asst. Prof. Dr. Okan Bozyurt
}

ORCID ID: https://orcid.org/0000-0002-7261-6125

Afyon Kocatepe University, Faculty of Arts and Sciences, Department of Geography, Afyonkarahisar - TURKEY

Ress. Asst. Enes Ertan Kulaksiz

ORCID ID: https://orcid.org/0000-0002-1238-3390

Afyon Kocatepe University, Faculty of Arts and Sciences, Department of Geography, Afyonkarahisar - TURKEY

\section{Artcile History}

Geliş: 11.02 .2021

Kabul: 18.05 .2021

On-line Yayın: 30.06.2021

Keywords

Natural Disaster

Landslide

Sensitivity Analysis

Babadağ

Denizli

\section{Research Article}

DOI:

http://dx.doi.org/10.29228/JASSS.47570

\section{Abstract}

In the Aegean Region, Denizli Babadağ district is an active landslide site. Babadağ has been known as a "disaster zone" by public institutions since 1941. Babadağ's Gündoğdu District was declared a "Disaster Exposed Zone" by the decision of the Council of Ministers on 06/02/2007 and numbered 11684. For this reason, this study was carried out in order to reveal both the current landslide situation and landslide sensitivity of Babadağ district. In order to detect landslide sensitivity, 12 parameters were based and GIS-based maps were created based on them. With AHP Template software developed by SCB Associates Ltd, landslide sensitivity analysis of Babadağ district was carried out using weight and sensitivity formulas of parameters. As a result of landslide analysis, very low, low, medium, high and very high sensitive landslide areas were detected. As a result of the determination; Babadağ district, $46.02 \%$ of the total area $(56.47$ $\mathrm{km}^{2}$ ) "medium sensitivity" while the settlements were found to have a "high sensitivity" rating. For this reason, due to Babadağ landslide directly occur in county town settlement, in next landslide, settlement areas are in danger of landslide. Due to the physical geography characteristics suitable for landslides, it has been revealed that work on landslide hazards and risks should be continued in residential areas and infrastructure works.

\section{Reference Information / Atıf Bilgisi}

Özdemir, M. A; Çırak, O; Bozyurt, O. ve Kulaksız, E. E. (2021). GIS Based Landslide Sensitivity Analysis of Babadağ District (Denizli/Turkey) Landslide Areas. Jass Studies-The Journal of Academic Social Science Studies, 14(85): 289-308. 


\title{
Babadă̆ İlçesi'nin (Denizli/Türkiye) CBS Tabanlı Heyelan Duyarlılık Analizi
}

\author{
Prof. Dr. Mehmet Ali Özdemir
}

Afyon Kocatepe Üniversitesi, Fen-Edebiyat Fakültesi, Coğrafya Bölümü, Afyonkarahisar - TÜRKİYE

\section{Oğuzhan Çırak}

Doktora Öğrencisi / Afyon Kocatepe Üniversitesi, Sosyal Bilimler Enstitüsü, Coğrafya Anabilim Dalı, Afyonkarahisar - TÜRKIYE

\section{Dr. Öğr. Üyesi Okan Bozyurt}

Afyon Kocatepe Üniversitesi, Fen-Edebiyat Fakültesi, Coğrafya Bölümü, Afyonkarahisar - TÜRKİYE

Arş. Gör. Enes Ertan Kulaksız

Afyon Kocatepe Üniversitesi, Fen-Edebiyat Fakültesi, Coğrafya Bölümü, Afyonkarahisar - TÜRKIYYE

\section{Makale Geçmişi}

Submitted: 11.02 .2020

Accepted: 18.05 .2021

Published Online: 30.06 .2021

Anahtar Kelimeler

Doğal Afet

Heyelan

Duyarlılık Analizi

Babadağ

Denizli

\section{Araştırma Makalesi}

DOI:
$\mathrm{Oz}$

Ege Bölgesinde, Denizli Babadağ ilçesi aktif bir heyelan sahasıdır. Babadağ, 1941 yılından beri kamu kuruluşlarınca "afet bölgesi" olarak bilinmektedir. Babadağ'ın Gündoğdu Mahallesi ise Bakanlar Kurulunun 06/02/2007 gün ve 11684 sayılı kararı ile "Afete Maruz Bölge" ilan edilmiştir. Bu nedenle Babadağ ilçesinin hem mevcut heyelan durumu hem de heyelan duyarlılığını ortaya koymak amacıyla bu çalışma yapılmıştır. Heyelan duyarlılığını tespit edebilmek için 12 parametre esas alınmış ve bunlardan yola çıkılarak CBS tabanlı haritalar oluşturulmuştur. SCB Associates Ltd. tarafından geliştirilen AHP Template yazılımı ile parametrelerin ağırlık ve duyarlılık formülleri kullanılarak Babadağ ilçesinin heyelan duyarlılık analizi gerçekleştirilmiştir. Heyelan analizinin sonucunda çok düşük, düşük, orta, yüksek ve çok yüksek duyarlı heyelan alanları tespit edilmiştir. Tespit neticesinde; Babadağ ilçesinin toplam alanın \%46,02's1 $\left(56,47 \mathrm{~km}^{2}\right)$ "orta duyarlılıkta" iken yerleşim birimleri "yüksek duyarlık" derecesine sahip olduğu ortaya konulmuştur. Bu nedenle Babadağ heyelanı doğrudan ilçe merkezi yerleşim alanında gerçekleştiği için sonraki heyelanlarda da yerleşim alanları tehlike altındadır. Heyelana uygun fiziki coğrafya özellikleri nedeniyle yerleşim alanlarında ve alt yapı çalışmalarında, heyelan tehlike ve riskine yönelik çalışmaların devam ettirilmesi gerektiği ortaya çıkmıştır. 


\section{INTRODUCTION}

The landslide was the product of local geological, hydrogeological and geomorphological conditions; affected by vegetation, land use and human activities; artificial or natural instability controlled by the frequency and severity of precipitation and seismic events (Soeters and Van Westen, 1996: 130). Landslides play an important role in shaping slopes and are one of the most common natural disasters that lead to loss of life and property (Özdemir, 1996: 195). Economic losses from mass movements in the world have reached 4 billion US Dollars and approximately 1000 people die annually due to landslide spree (Gokceoglu, 2016: 1). According to the AFAD (Turkey, Ministry of Interior Disaster and Emergency Management Presidency) information inventory of Gökçe et al. (2008: 11) "it is the most common type of natural disaster with a rate of $45 \% "$.

Disaster-sized events cause long-term economic deterioration, population displacement and adverse effects on the natural environment. Effective implementation of geotechnical research, good engineering practices and land use management regulations can reduce landslide hazards. As a matter of fact, although they are natural disasters, some of the landslides can be observed in nature and their pre-formation references can be predicted. Preventive efforts can be prevented. The geomorphology of the research area has significantly determined the fate of the region. Babadağ district center was severely damaged due to landslide problems and the prediction of irreparable results necessitated measures. Babadağ's geomorphology and landslides have completely blocked the economic development and spatial growth of the district.

Today, many methods are used in research estimating hazardous, active landslide sites. It is partly possible to analyze and fight with various methods and techniques for landslide events, whose formations and types vary from region to region, both in the world and in Turkey. Sensitivity analyses are important and necessary to reduce the possible effects of the landslide by identifying hazardous and risky areas. Landslide susceptibility maps produced as a result of sensitivity analyses "are not usually about which region, when and what size there will be landslides, but which regions are more susceptible to landslides and which are less sensitive (Gökçeoglu and Ercanoğlu, 2001: 201). Sensitivity analyses of $\mathrm{H}$ are important for reducing the economic losses related to these processes, revealing the danger and risk of mass movements.

Babadağ (Denizli) landslide area, in the southern part of the Great Menderes Plain in the Aegean Region of Turkey, on the south section of meander graben is tectonic horst. It is located on the northern slopes of Babadağ (summit, $2300 \mathrm{~m}$ ) and is $32 \mathrm{~km}$ from Denizli (Figure 1). 


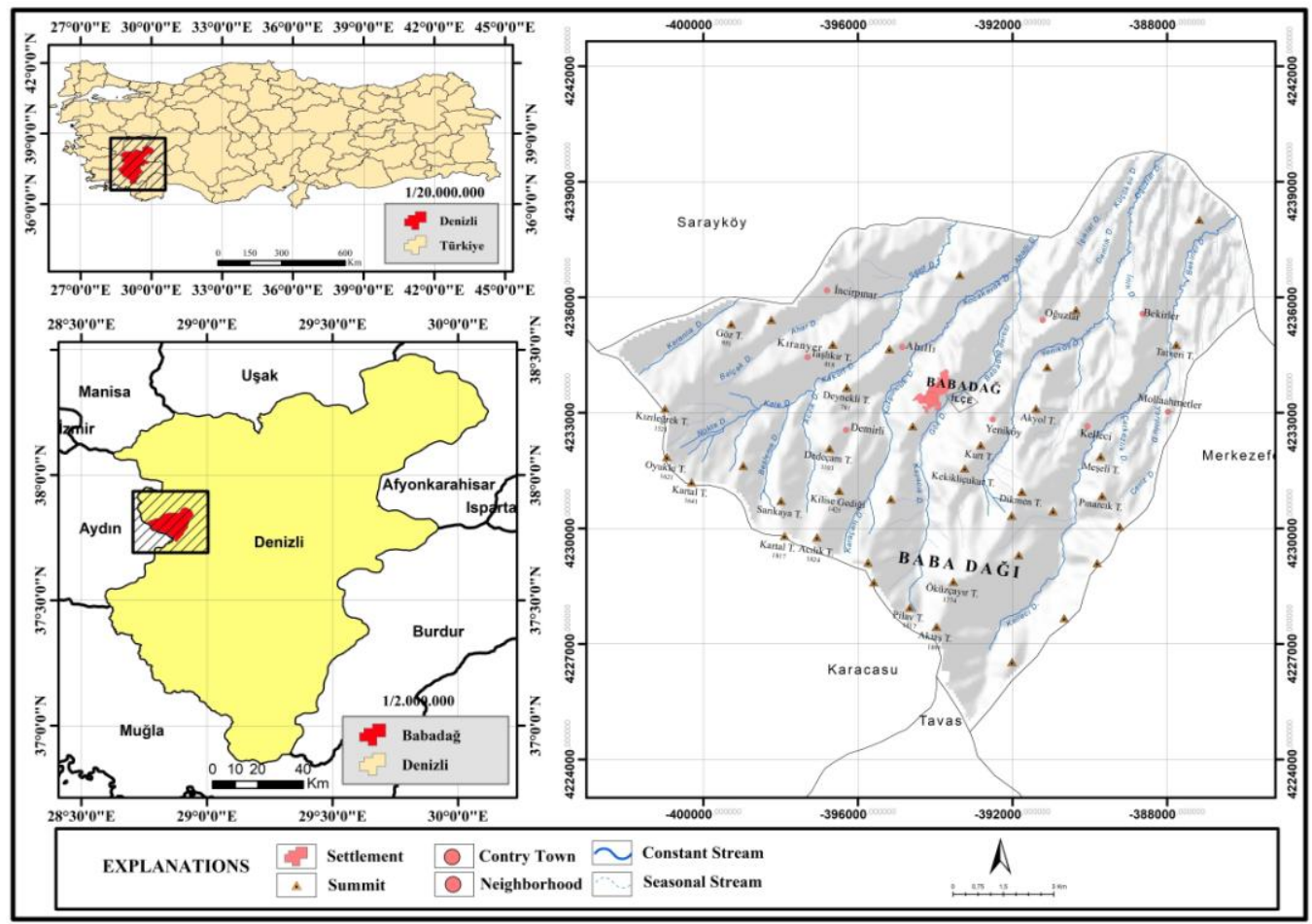

Figure 1: Location map of the research area.

\section{MATERIAL - METHOD}

Books, thesis, articles, reports, journals, newsletters and statistical data were scanned in libraries belonging to different institutions related to the Babadağ (Denizli) landslide and a wide range of literature was reached. The work in question was directly utilized from some of them and some in terms of method. Land observations performed at different times provided data about landslides and regions.

In the literature, the methods and parameters used during the preparation of landslide sensitivity maps have not yet established a consensus among the researchers and the parameters of the field in which each researcher is working a large number of parameters and methods are used (Gökçeoğlu and Ercanoğlu, 2001: 192). The parameters used for this study are provided by the observation of literature and terrain. The processing stages of the data, parameters and analyses used to obtain the landslide sensitivity map of the work area are given in figure 2 . The data type-resources-data required for the creation of maps of these parameters are given in figure 2 and chart 1. 


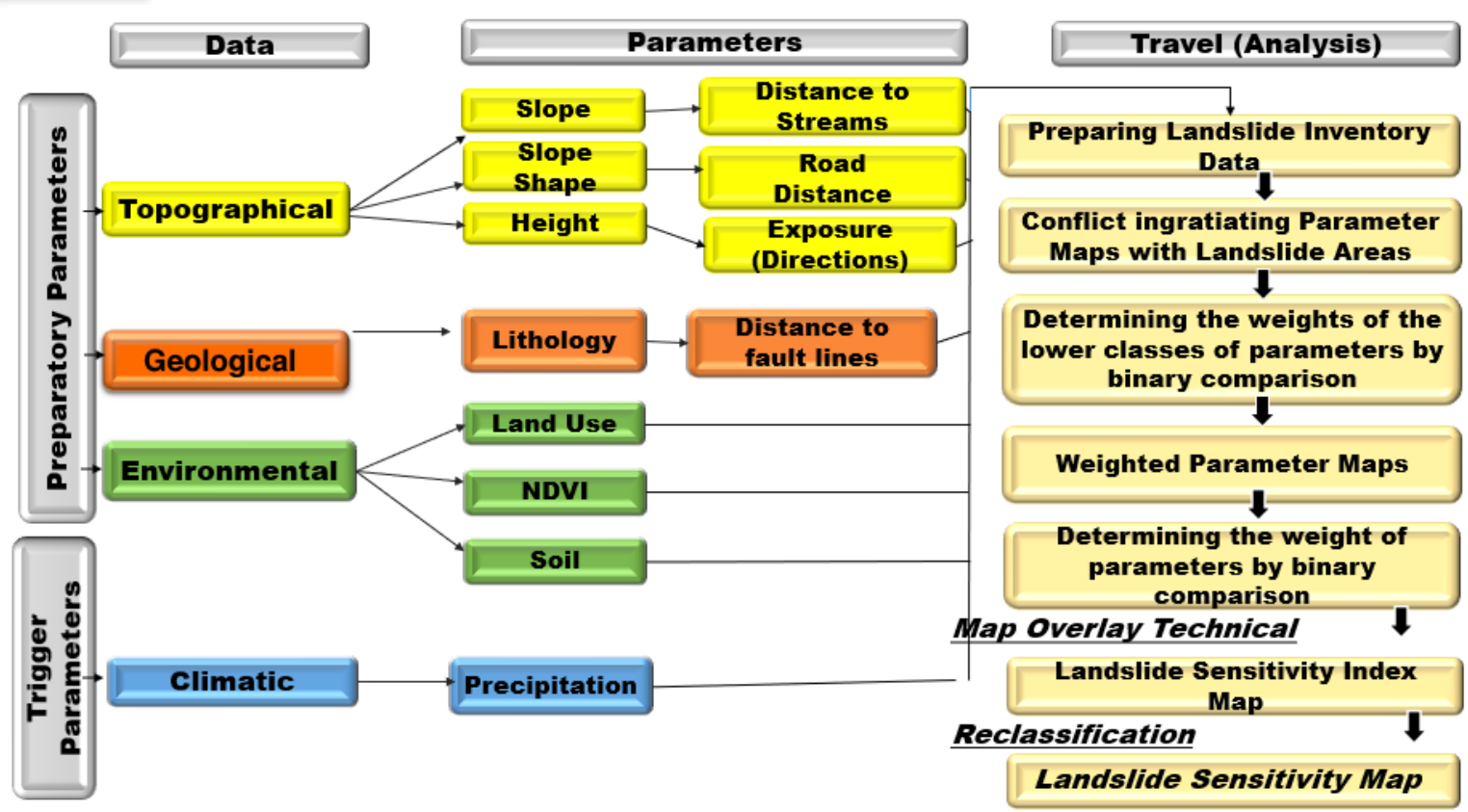

Figure 2: Process flow sheet of data, parameters and analyses determined to obtain a landslide sensitivity map of the worksite.

Chart 1: Data and Data Sources Used in the Study.

\begin{tabular}{|c|c|c|}
\hline Data type & Data source & Data generated \\
\hline $\begin{array}{c}\text { Topography maps (1/100,000 scale } \\
\text { M21 Plate) 1/25,000 Scale (M21-b3, }\end{array}$ & $\begin{array}{c}\text { Map General } \\
\text { Command }\end{array}$ & $\begin{array}{c}\text { Map Basic Data } \\
\text { (hill, settlement, etc.) } \\
\text { Distance to Roads-Streams }\end{array}$ \\
\hline GDEM (Digital Elevation Model) & ERSDAC & $\begin{array}{c}\text { Height, Slope, View, Slope } \\
\text { shape }\end{array}$ \\
\hline $\begin{array}{c}\text { Geological map (M21 Plate, } \\
\text { Scale:1/100,000) }\end{array}$ & $\begin{array}{c}\text { Mineral Exploration } \\
\text { and Exploration } \\
\text { General Directorate }\end{array}$ & $\begin{array}{c}\text { Lithology } \\
\text { Distance to fault lines }\end{array}$ \\
\hline $\begin{array}{c}\text { Babadağ/Denizli Automatic } \\
\text { Meteorological Observation Station } \\
\text { Precipitation Data }\end{array}$ & $\begin{array}{c}\text { Meteorology Affairs } \\
\text { General Directorate }\end{array}$ & Precipitation-Temperature \\
\hline $\begin{array}{c}\text { 1/25.000 Scale National Soil } \\
\text { Database. }\end{array}$ & $\begin{array}{c}\text { Ministry of Agriculture } \\
\text { and Forestry }\end{array}$ \\
\hline Maps & $\begin{array}{c}\text { Ministry of Agriculture } \\
\text { and Forestry } \\
\text { Directorate General for } \\
\text { Agricultural Reform }\end{array}$ & Land Use \\
\hline 100.000 Scale Terrain Inventory & \\
\hline Maps & & \\
\hline
\end{tabular}




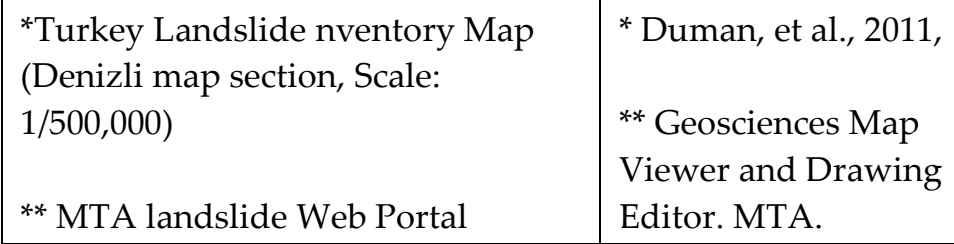

Babadağ/Denizli Landslide Inventory Map

The most preferred method used to detect landslide sensitivity of a site is Analytic Hierarchy Process (Ayalew and Yamagishi, 2005: 17; Moradi et al. 2012: 671; Özşahin 2014: 168). Yalcin (2008: 1) argued that the AHP method yielded much more realistic results than some other methods. Özşahin (2014: 179) argues that the GIS-based AHP method yields healthy and usable results in landslidesensitive studies. Çellek et al. (2015: 59-90) "From the studies conducted in the literature between 20002015, he examined the studies that were created with the process of Analytic hierarchy and a map of landslide susceptibility, risk and danger, and in particular the last three an increase in the use of AHP per year."

This study was carried out using AHP Template software developed by AHP, SCB Associates Ltd. For this purpose, the purpose of working with the first purpose was determined and the criteria affecting the selection were put forward for this purpose. Later, taking these criteria into consideration, alternatives were identified and a hierarchical structure was established (Dağdeviren and Eren, 2001: 43; Özşahin, 2014: 171). Then the criteria and alternatives identified were compared by Saaty (1994: 26), according to the severity scale placed on the first month and with the help of this scale ranked between 13. In the process of comparative decision-making and the creation of the preference matrix, the parameters first identified were compared with each other. When there were $n(n-1) / 2$ comparisons were made at the hierarchy level to be compared in this comparison, $n(n-1) / 2$ were compared and each comparison was arranged as a matrix" (Öztürk and Batuk, 2007: 90; Özşahin, 2014: 172). Then the criteria and alternatives determined in the scale, using the AHP Template program, to apply the consistency of percentage severity weights (Kwiesielewiczk and Uden, 2004: 714; Özşahin, 2014: 472; Saaty and Vargas, 2001: 9) have been obtained. In determining the comparisons of intermediates and the sub-criteria (impact values) of the parameters, the produced Babadağ landslide inventory map and data layers were compared. Thus, the determined weight values are analysed in the boiler suitable for the field. As a matter of fact, this study was found to be $10 \%$ less than the consistency of the matrixes.

Chart 2: Weight Values of Criteria and Alternatives Evaluated in The Study.

\begin{tabular}{|c|c|c|c|c|c|}
\hline Criteria & Alternatives & $\begin{array}{c}\text { Total Field } \\
\text { Percentage } \\
\text { (a) }\end{array}$ & $\begin{array}{c}\text { Landslide } \\
\text { Area } \\
\text { Percentage } \\
\text { (b) }\end{array}$ & $\begin{array}{c}\text { Frequency } \\
\text { Ratio (b/a) }\end{array}$ & $\begin{array}{c}\text { AHP } \\
\text { Alternative } \\
\text { Weight } \\
\text { Values }\end{array}$ \\
\hline & Alluvial (Quaternary) & 0,49 & 0,28 & 0,57 & 0,085 \\
\cline { 2 - 6 } & Pebble (Quaternary) & 2,98 & 73,78 & 24,72 & 0,088 \\
\cline { 2 - 6 } & $\begin{array}{c}\text { Hillside Debris-Puddle } \\
\text { Cone- (Quaternary) }\end{array}$ & 0,19 & 0,40 & 2,11 & 0,1 \\
\cline { 2 - 6 } & $\begin{array}{c}\text { Pebble-Sandstone- } \\
\text { Mudstone-Marn- } \\
\text { Claystone (Pliocene) }\end{array}$ & 45,78 & 21,00 & 0,46 & 0,132 \\
\hline
\end{tabular}




\begin{tabular}{|c|c|c|c|c|c|}
\hline \multirow[t]{9}{*}{ Lithology } & $\begin{array}{l}\text { Pebble-Sandstone- } \\
\text { Mudstone (Upper } \\
\text { Miocene-Pliocene) }\end{array}$ & 0,30 & 2,20 & 7,34 & 0,231 \\
\hline & $\begin{array}{l}\text { Marble (Jura- } \\
\text { Cratecaeous) }\end{array}$ & 0,35 & 1,46 & 4,21 & 0,081 \\
\hline & $\begin{array}{l}\text { Quartzite-Quartzite } \\
\text { schist (Paleozoic) }\end{array}$ & 4,90 & 0,89 & 0,18 & 0,041 \\
\hline & Marble (Paleozoic) & 0,22 & 0,00 & 0,00 & 0,05 \\
\hline & Schist (Paleozoic) & 3,81 & 0,00 & 0,00 & 0,045 \\
\hline & $\begin{array}{l}\text { Quartzite-Quartzite } \\
\text { schist (Upper } \\
\text { Paleozoic) }\end{array}$ & 0,15 & 0,00 & 0,00 & 0,034 \\
\hline & $\begin{array}{l}\text { Schist (Upper } \\
\text { Paleozoic) }\end{array}$ & 0,13 & 0,00 & 0,00 & 0,057 \\
\hline & $\begin{array}{l}\text { Quartzite-Quartzite } \\
\text { schist (Precambrian) }\end{array}$ & 0,73 & 0,00 & 0,00 & 0,039 \\
\hline & $\begin{array}{l}\text { Gneiss- Mica-schist } \\
\text { (Precambrian) }\end{array}$ & 39,97 & 0,00 & 0,00 & 0,016 \\
\hline \multirow{6}{*}{$\begin{array}{l}\text { Distance to } \\
\text { fault lines } \\
(\mathrm{m})\end{array}$} & $0-100$ & 22,64 & 26,85 & 1,19 & 0,379 \\
\hline & $100-250$ & 27,91 & 31,31 & 1,12 & 0,249 \\
\hline & $250-500$ & 24,80 & 31,65 & 1,28 & 0,16 \\
\hline & $500-750$ & 10,65 & 6,88 & 0,65 & 0,102 \\
\hline & $750-1000$ & 4,37 & 1,45 & 0,33 & 0,065 \\
\hline & $1000->$ & 9,63 & 1,86 & 0,19 & 0,043 \\
\hline \multirow[t]{6}{*}{ Height (m) } & $261-500$ & 16,45 & 13,01 & 0,79 & 0,379 \\
\hline & $501-750$ & 29,55 & 60,24 & 2,04 & 0,249 \\
\hline & $751-1000$ & 18,75 & 13,65 & 0,73 & 0,16 \\
\hline & $1001-1250$ & 13,43 & 6,75 & 0,50 & 0,102 \\
\hline & $1251-1500$ & 11,75 & 2,96 & 0,25 & 0,065 \\
\hline & 1501-> & 10,07 & 3,41 & 0,34 & 0,043 \\
\hline \multirow{3}{*}{$\begin{array}{l}\text { Inclination } \\
\text { Shape }\end{array}$} & Convex & 39,42 & 38,88 & 0,99 & 0,539 \\
\hline & Flat & 19,89 & 28,78 & 1,45 & 0,164 \\
\hline & Concave & 40,69 & 32,30 & 0,79 & 0,297 \\
\hline \multirow{5}{*}{$\begin{array}{c}\text { Inclination } \\
(\%)\end{array}$} & $0-15$ & 33,53 & 42,60 & 1,27 & 0,062 \\
\hline & $15-25$ & 37,99 & 45,81 & 1,21 & 0,099 \\
\hline & $25-35$ & 20,66 & 8,04 & 0,39 & 0,161 \\
\hline & $35-45$ & 6,38 & 2,93 & 0,46 & 0,262 \\
\hline & $45->$ & 1,45 & 0,58 & 0,40 & 0,416 \\
\hline \multirow{9}{*}{$\begin{array}{l}\text { Exposure } \\
\text { (Directions) }\end{array}$} & Flat & 9,25 & 5,96 & 0,64 & 0,023 \\
\hline & North & 18,60 & 16,27 & 0,87 & 0,289 \\
\hline & Northeast & 16,69 & 17,41 & 1,04 & 0,175 \\
\hline & East & 11,09 & 18,73 & 1,69 & 0,125 \\
\hline & Southeast & 1,68 & 3,46 & 2,06 & 0,081 \\
\hline & South & 1,00 & 1,42 & 1,41 & 0,053 \\
\hline & Southwest & 7,49 & 8,55 & 1,14 & 0,046 \\
\hline & West & 22,83 & 18,34 & 0,80 & 0,034 \\
\hline & Northwest & 11,29 & 9,84 & 0,87 & 0,174 \\
\hline
\end{tabular}




\begin{tabular}{|c|c|c|c|c|c|}
\hline \multirow{5}{*}{$\begin{array}{l}\text { Precipitation } \\
(\mathrm{mm})\end{array}$} & $957-1.100$ & 36,11 & 55,72 & 1,54 & 0,062 \\
\hline & $851-950$ & 27,27 & 30,95 & 1,14 & 0,099 \\
\hline & $751-850$ & 21,23 & 7,66 & 0,36 & 0,161 \\
\hline & $651-750$ & 14,11 & 4,99 & 0,35 & 0,262 \\
\hline & $561-650$ & 1,29 & 0,68 & 0,53 & 0,416 \\
\hline \multirow{5}{*}{$\begin{array}{l}\text { Distance to } \\
\text { streams (m) }\end{array}$} & $0-100$ & 24,62 & 15,00 & 0,61 & 0,416 \\
\hline & $100-250$ & 28,32 & 26,57 & 0,94 & 0,262 \\
\hline & $250-500$ & 28,19 & 38,53 & 1,37 & 0,161 \\
\hline & $500-750$ & 12,94 & 16,44 & 1,27 & 0,099 \\
\hline & $750->$ & 5,92 & 3,46 & 0,58 & 0,062 \\
\hline \multirow[t]{5}{*}{ Soil type } & $\begin{array}{c}\text { Red brown } \\
\text { Mediterranean soil }\end{array}$ & 4,80 & 15,54 & 3,24 & 0,099 \\
\hline & $\begin{array}{l}\text { No lime brown forest } \\
\text { soil }\end{array}$ & 28,03 & 66,27 & 2,36 & 0,083 \\
\hline & $\begin{array}{l}\text { No lime brown forest } \\
\text { soil }\end{array}$ & 18,93 & 16,27 & 0,86 & 0,067 \\
\hline & Rendzinas & 35,15 & 1,93 & 0,06 & 0,471 \\
\hline & Regosols & 13,10 & 0,00 & 0,00 & 0,083 \\
\hline \multirow[t]{7}{*}{ Land Use } & Settlement areas & 1,19 & 15,49 & 12,99 & 0,056 \\
\hline & Forests & 37,75 & 41,85 & 1,11 & 0,202 \\
\hline & Heath & 21,69 & 10,81 & 0,50 & 0,08 \\
\hline & Mere & 30,76 & 19,87 & 0,65 & 0,275 \\
\hline & Dry agriculture & 3,48 & 10,32 & 2,97 & 0,105 \\
\hline & Vineyard & 3,41 & 1,67 & 0,49 & 0,08 \\
\hline & Naked Cliff & 1,71 & 0,04 & 0,02 & 0,058 \\
\hline \multirow[t]{5}{*}{ NDVI } & $0,5-0,6$ & 24,94 & 30,37 & 1,22 & 0,073 \\
\hline & $0,4-0,4$ & 38,90 & 37,21 & 0,96 & 0,11 \\
\hline & $0,4-0,3$ & 26,79 & 22,41 & 0,84 & 0,154 \\
\hline & $0,3-0,3$ & 8,51 & 8,90 & 1,05 & 0,391 \\
\hline & $00,2-0,2$ & 0,87 & 1,15 & 1,32 & 0,272 \\
\hline \multirow{7}{*}{$\begin{array}{c}\text { Road } \\
\text { Distance (m) }\end{array}$} & $0-100$ & 12,23 & 13,02 & 1,06 & 0,032 \\
\hline & $100-250$ & 13,14 & 21,01 & 1,60 & 0,051 \\
\hline & $250-500$ & 17,05 & 29,70 & 1,74 & 0,071 \\
\hline & $500-750$ & 11,70 & 15,43 & 1,32 & 0,107 \\
\hline & $750-1000$ & 9,49 & 7,93 & 0,83 & 0,161 \\
\hline & $1000-2000$ & 21,45 & 8,15 & 0,38 & 0,225 \\
\hline & 2000-> & 14,93 & 4,78 & 0,32 & 0,353 \\
\hline
\end{tabular}

The data obtained by land and office studies for the determination of landslide sensitivity by AHP method and the database in schedule 2 have been established. At the final stage of the method, the weight values obtained were engraved on maps of alternative factors in vector data format. As a result of the analysis conducted in the study, Geographic Information Systems (GIS) methods and techniques, taking into account the values of all parameters, and ArcGIS/ArcMap 10 package program, 10x10 m resolution, raster-based grid maps produced. As a result, a landslide sensitivity map of the field was obtained. 


\section{FINDINGS}

The first step in landslide sensitivity assessments is to learn about landslides that occurred in the past. Because it is assumed that future landslides take place under similar conditions as landslides that have occurred in the present and past (Akinci et al., 2011: 19; Kumtepe et al., 2009: 3; Varnes, 1984). For this purpose, landslide inventory map of the work area was made. As can be seen from the Babadağ inventory map, the district is an active and old landslide site (Figure 4). As a matter of fact, other geography conditions, especially the geomorphological, tectonic features and climate of Babadağ district are suitable as long as landslides have become. The height of the values, lacustrine Pliocene claystones and sandstone and marn rocks such as deep splitting by streams resulting from the sloped slopes laid the groundwork for the landslide. Neotectonic combined with the cascading topography of the severity faults and the strong relief energy of the streams the great elevation difference between the Great Menderes plain and Babadağ, the widespread use of claystone and marns, the main landslides in the field causes.
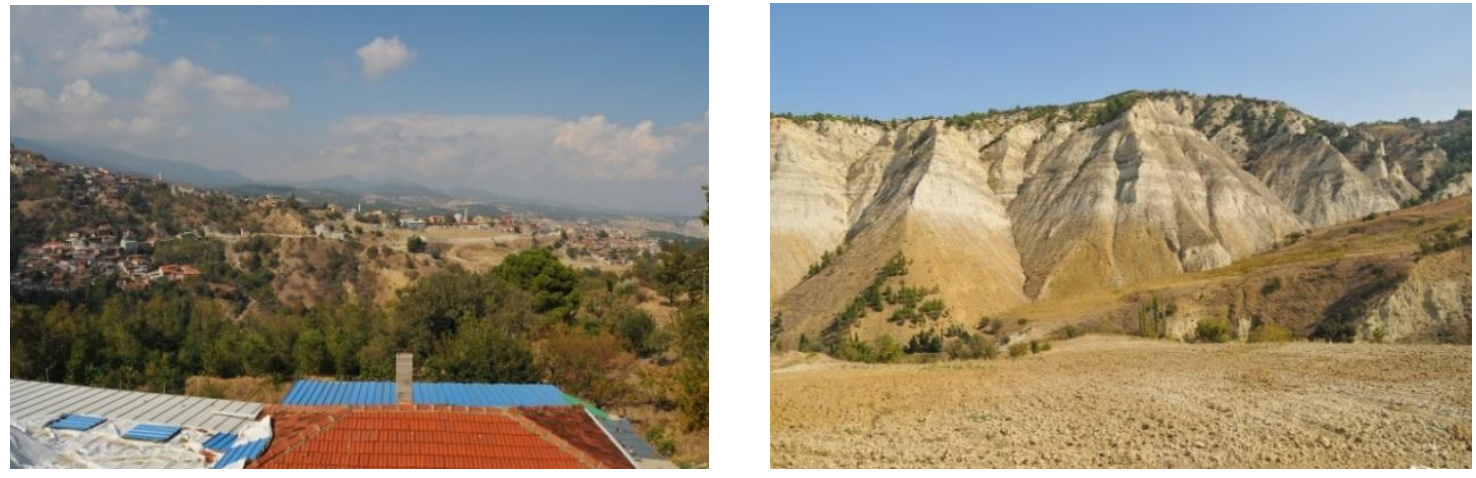

Figure 3: a. Babadağ (Denizli) landslide field b. landslide sensitive Upper Miocene-Pliocene claystones and marns on the badlands, tomorrow, flood erosion and stream active landslides are seen towards the edge. 


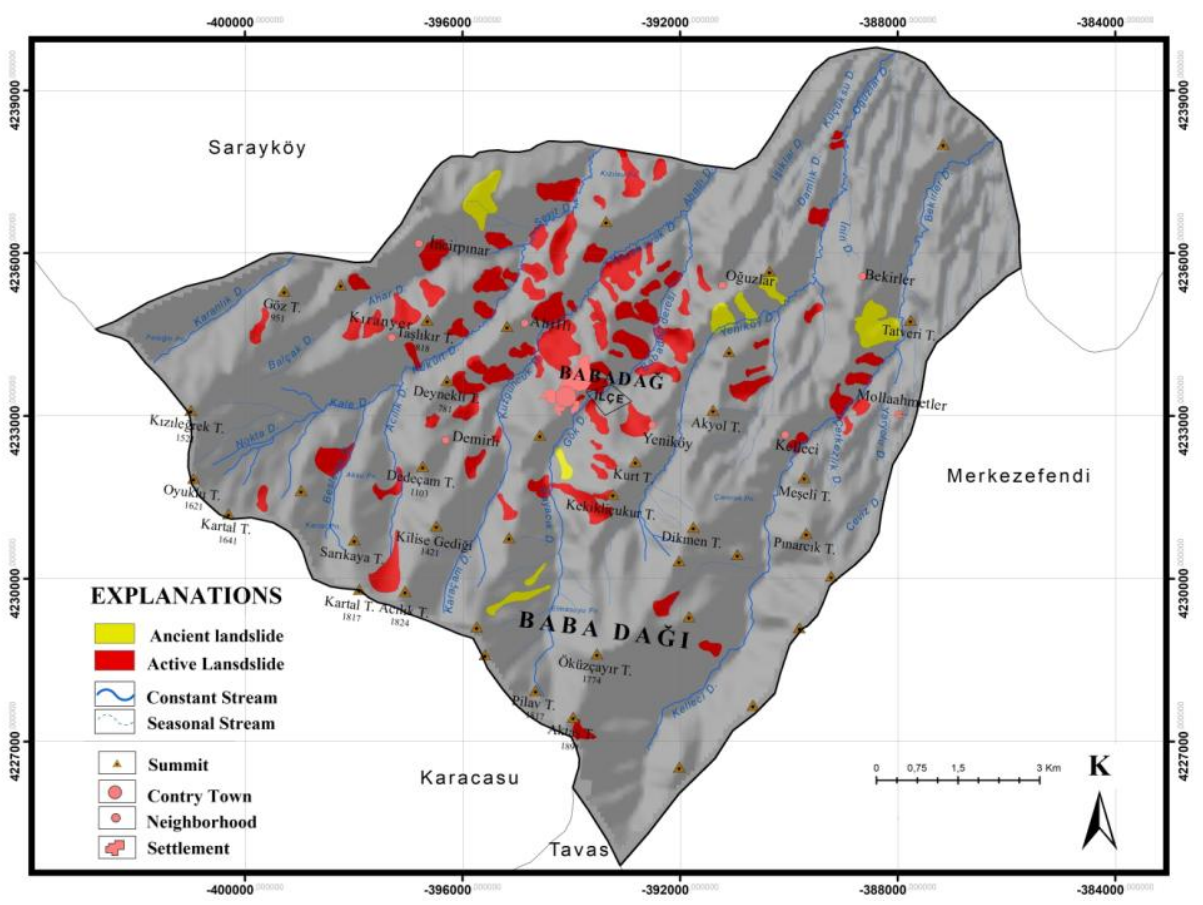

Figure 4: Babadağ District Landslide Inventory Map.

Landslides have occurred in Babadağ in the past and continue to this day. Today, movement and deformation of the type of "creep" are observed. Flowing continues continuously but gradually. The main reason for these landslides is the structure of the ground. A large part of Babadag district center is a landslide material with high decomposition and lique faction of impermeable rocks such as claystone and marn. As a result of air and water contact, the marns, which have low resistance properties, are easily dispersed and mechanically broken down. Clay, on the other hand, is slippery with water and the high rainfall in the field is saturated with $907 \mathrm{~mm}$ and flows into the flow, shifting itself and its units.

"The determinant of climatic conditions in landslide formation is particularly evident in precipitation" (Yalcin, 2008). The average annual rainfall is considered an important factor for landslide hazard analysis (Kayastha et al., 2013: 790). Because Babadağ district receives a high amount of precipitation, the rocks and debris that form the ground allow abundant water to leak, which creates landslide activity. 




Figure 5: Geological Map of Babadağ District.

The research area is on the highly active tectonic structure formed by normal faults with NW-SE pointing, which borders the Great Menderes depression basin, including Denizli. Neotectonic movements increase deformation in areas close to the fault and weaken the materials that make up the ground (Figure 5). As a matter of fact, fault steepness, steps formed, rocks and layers were tilted, ridges were multiplied by fault and laid the groundwork for the landslides in the area connected to the Babadağ and Yeniköy faults passing through the area where Yeniköy neighborhood is located.

$89.81 \%$ of the landslides in the field are seen on fault lines $0-500 \mathrm{~m} 10.19 \%$ in areas $500 \mathrm{~m}$ or more (Chart 2 and Figure 6). The cutting of sand, clay and marn rocks by faults that develop parallel to each other, such as the staircase step, plays an important role in the formation of different deformations. The fact that Babadağ fault is active in the research area and that the land is saturated with water during the rainy season creates the risk of landslide disasters. 


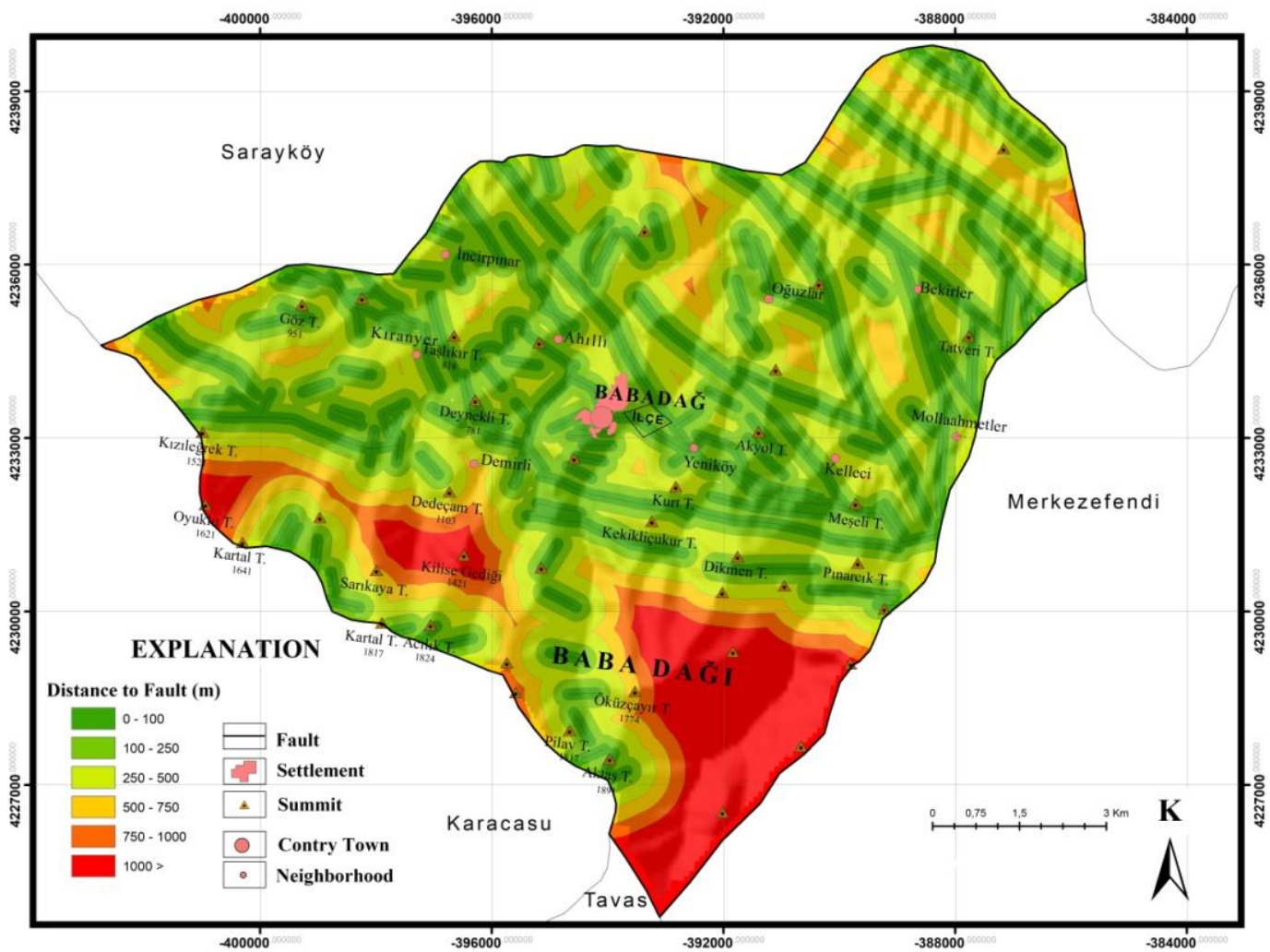

Figure 6: Distance Map to Fault Lines in Babadağ District.

In Babadağ, the lithological state of the ground, slopes and streams emerge as an important factor together on the landslides of the work site. The clay that forms the slopes, the marns become saturated with water and act with the effect of gravity. Water, on the other hand, increases the weight by reducing the equilibrium angle and reduces friction against it, making movement easier. In the research area, the streams have deep valleys and break the stability of the slopes by carving the patches from the bottom. When the distribution of landslides to the distances to the streams $(\mathrm{m}), 38.53 \%$ of the landslides were $250-500 \mathrm{~m}, 26.57 \%$ were $100-250 \mathrm{~m}, 16.44 \%$ were $500-750 \mathrm{~m}, 15 \%$ 0-100 m, 3.46\% $750 \mathrm{~m}$ and above has occurred at distances. These data show that fluoride erosion in landslide formation also increases as the river bed approaches. 




Figure 7: Looking east from Gundogdu District from Babadağ District Center, normal and reverse faults that cut the Upper Miocene-Pliocene lake units.

In the preparation of landslide sensitivity maps, inclination is used as an important parameter in terms of the formation and development of the landslide. As my enthusiasm increased, sensitivity to landslides increased (Dölek and Avc1, 2016: 121; Gökceoğlu and Ercanoğlu, 2001: 197; Özşahin, 2013: 50, 2014: 174; Pektezel, 2015: 803; Sunkar and Avc1, 2016: 17).

Slope is one of the most important morphological parameters that control the range of motion of mass movements. Inclination; the formation of the landslide, its livelihood to the movement and the transportation of the material at the same time it supervises. The effect of the slope parameter in the field is determined and used by Bijukchhen et al. (2013) and Kayastha et al. (2013: 2732) and Özşahin (2014: 174) and Pektezel (2015: 803) is determined by inclination classes. Based on these classification ranges; The proportional distribution of landslides to slope groups formed in Babadağ district is $45.81 \%$; Areas with a slope of $0-15 \%$ are $42.6 \%$; Areas with a slope of $25-35 \%$ are $8.08 \%$; Areas with a $35-45 \%$ inclination of $2.93 \% ; 45 \%$ - > areas with slopes cover $0.58 \%$ area (Figure 7 ). 




"Cliffs consists of flat, concave and convex slopes. The curvature of the slopes also has a decisive effect on the landslide"(Pektezel, 2015: 803). The inclination shape plays a role in the landslide formation process by controlling the acceleration or slowdown of the flow (Akinci et al., 2011: 21; Kayastha et al., 2013: 789; Nefeslioglu et al., 2008: 409). The slope is higher on the convex slopes than the concave slopes. Therefore, soil humidity on convex slopes is relatively low due to the rapid movement of water (Mater, 2004: 45). The distribution of landslides occurring in the field of adjustment to the inclination groups is $38.92 \%$ convex, $32.30 \%$ concave and $28.78 \%$ flat on the slopes. Naturally, the most landslides occurred on convex slopes (Chart 2).

The exposure factor plays an ambient preparation role by controlling heating, precipitation, humidity, freezing of the ground, time of snow and ice staying on the ground, dissolving processes for mass movements. Low heat reduces evaporation and increases humidity compared to south-facing slopes. The general precipitation aspect of area affects the liquefaction of the mass. In the field, $43.54 \%$ of the landslides are scattered in the view groups, $13.43 \%$ in the south, $5.96 \%$ straight, $18.73 \%$ east and $18.34 \%$ on the western slopes. Especially on the north-sided slopes, the reason for the intensification of the landslide is the geomorphological feature of the district, as well as the vegetation, wind effect, precipitation etc. as a result of the process of exposure to sunlight.

The determinant and triggering of climatic conditions in the formation of Babadağ landslides is especially evident in precipitation. Kayastha et al. (2013: 790) landslides are considered to be an important factor in the annual average rainfall for hazard analysis. As a matter of fact, the rainfall of Babadağ district between 500-1200 mm causes the streams to change beds and lateral and vertical slope erosion. Landslides occur frequently on the slopes of Babadağ-Gökdere-Ahıllı-Kocakavak-Kuzguncuk valleys. On Babadağ's faulty and sloping topography, the slope and elevation are high, the rivers that 
are strengthened as a result of the rapid flow of precipitation abrasion is increasing and the slope balance is deteriorating. Like rainwater, snow melts cause erosion and landslides as temperatures rise from spring.

By utilizing Remote Sensing methods, vegetation properties of the worksite have been revealed. "In remote sensing technique, vegetation densities are determined by the help of plant indexes" (Tombuş, 2005: 65). Vegetation Density of Babadağ district, what is the normalized plant difference index (Normalized Difference Vegetation Index) (NDVI) manufactured accordingly.

According to NDVI from Landsat 8 satellite image of the work site dated May 18, 2018, vegetation density was evaluated. Because vegetation indices are used as a factor affecting landslides in landslide susceptibility studies (Althuwaynee et al., 2012).

Landsat 8 satellite image NDVI with the following formula;

$$
\text { NDVI }=\frac{\text { Band5 }- \text { Band } 4}{\text { Band5 }+ \text { Band } 4}
$$

has been obtained. NDVI values in Babadağ district range from 0.6 to 0.02 . The areas where NDVI (Normalized Difference Vegetation index) values are close to 1 indicate areas with high plant closures (northwest of the district center), and areas below 0 show areas devoid of vegetation (Figure 9).

The distribution of NDVI groups in the total area of the field is as follows;

$0.5-0.6 \%$ to $24.94 \%$; $0.4-0.4 \%$ to $38.9 \%$; $0.4-0.3 \%$ to $26.79 \%$; $0.3-0.3 \%$ covers $8.51 \%$ and $00.2-0.2 \%$ area (Figure 8).

Distribution of NDVI groups to landslide area; $0.5-0.6 \%$ to $30.37 \% ; 0.4-0.4 \%$ between $37.21 \%$, $0.4-0.3 \%$ to $22.41 \%$; $0.3-0.3 \%$ to $8.9 \%$; $00.2-0.2$ is $1.15 \%$ (Figure 8 ).



Figure 9: Distribution of NDVI Groups to Spatial and Landslide Area.

The weight of the trees in the forest area, which accounts for $46.77 \%$ of the total land in Babadag district, increases the normal and slip stresses on the slope, which adversely affects the stability of the material. At the same time, the forest cover affects the superficial flow of rainwater and streams flowing along the slope, allowing the bedrock to decompose and dissolve by leaking deeper. 


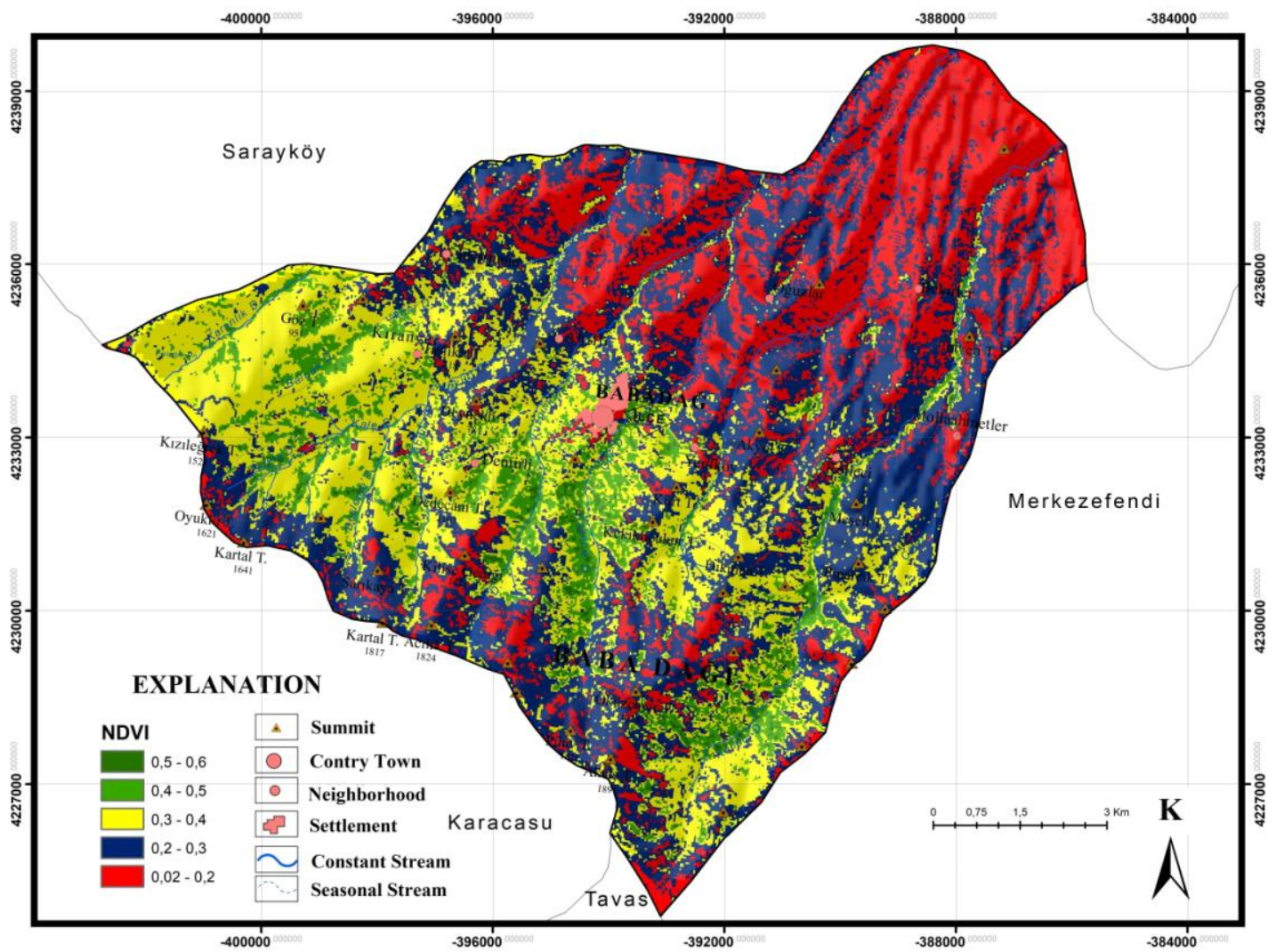

Figure 10: Babadağ NDVI (Normalized Difference Vegetation Index) map

Not too many landslide moments have occurred within the metamorphic units in the southern parts of the work area. The landslides that have been on unit stook place in a superficial veil separated by road expansion, construction excavations and river erosion. Interventions on the slopes (opened roads, excavations) cause load changes in the heel of the slopes as well as play a role in shaping topography.

7 classes have been created for distance to the road in the survey area. $79.16 \%$ of landslides are between $0-750 \mathrm{~m} ; 20.84 \%$ were seen in areas that were more than $750 \mathrm{~m}$ away. Places between $0-750 \mathrm{~m}$ on the road in the working area are $54.12 \%$ of the total area. This indicates that proximity to the road is the factor that triggers the landslide (Chart 2). 


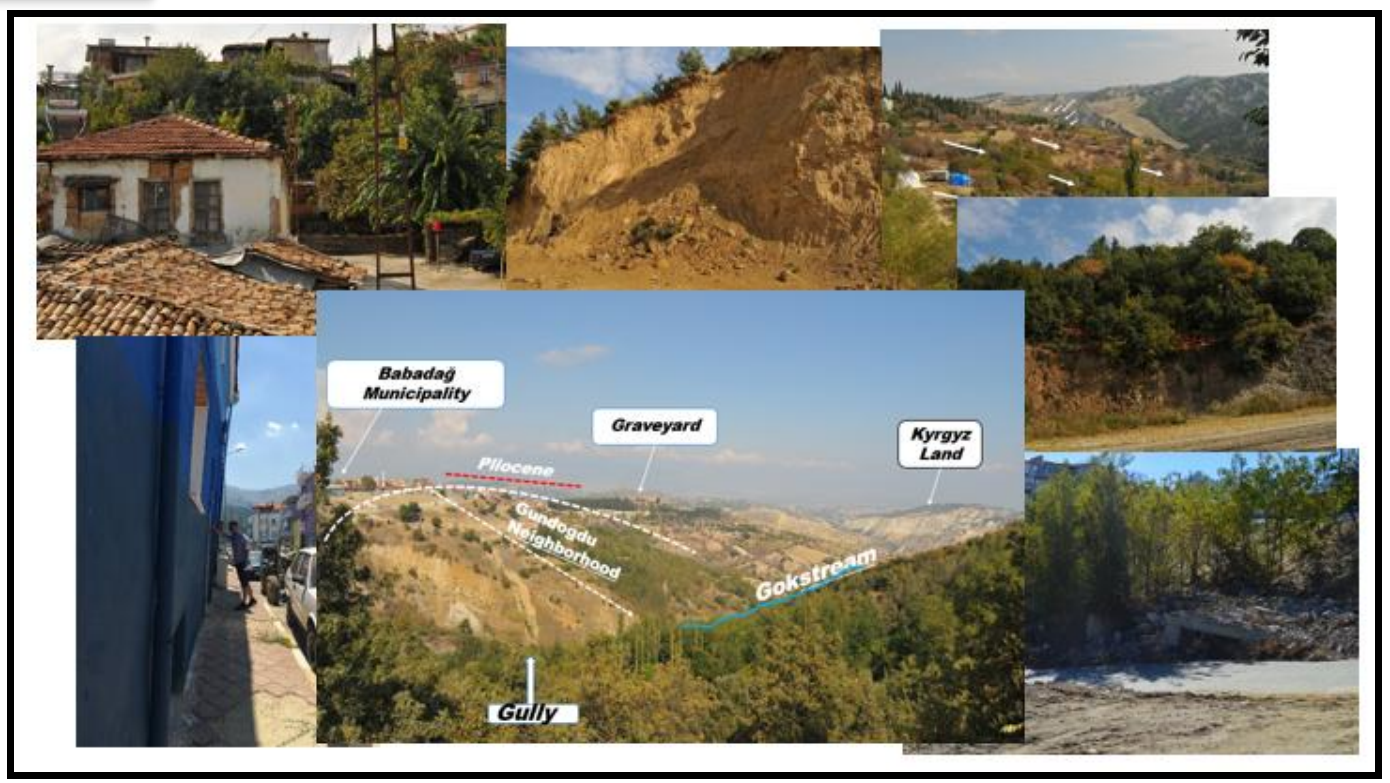

Figure 11: Some mass movements seen in Babadağ District. From left to right, respectively, soil flows, gravestones, flows in the cover of decomposition on the schist, collision in houses, bending on poles, Babadağ landslide area and structures are seen.

\section{LANDSLIDE SENSITIVITY ANALYSIS}

With this study, which applied the AHP method based on GIS, Babadağ district's sensitivity to landslides was determined. As a result of the detection; $46.02 \%\left(56.47 \mathrm{~km}^{2}\right)$ of the total area of Babadağ district was found to be in danger of landslides at "moderate sensitivity" (Figure 12). Areas with high risk of landslides are slopes with high slopes and precipitation values. In addition, the existing lithology here provides suitable material for landslides.

According to the analysis of landslide sensitivity with Analytic hierarchy process (AHP), 1\% (1.23 $\left.\mathrm{km}^{2}\right)$ of Babadag district is very high, $17.88 \%\left(21.94 \mathrm{~km}^{2}\right)$ is high, $46.02 \%\left(56.47 \mathrm{~km}^{2}\right)$ medium, $31.92 \%(39.17$ $\left.\mathrm{km}^{2}\right)$ low, $3.17 \%\left(3.9 \mathrm{~km}^{2}\right)$ is in danger of landslides at very low sensitivity (Figure 10). Babadağ is part of the district center and the high topography behind it is very high and high sensitivity. In the southern parts where metamorphic rocks are located, valley floors and areas with low slope, the risk of landslides is lower.

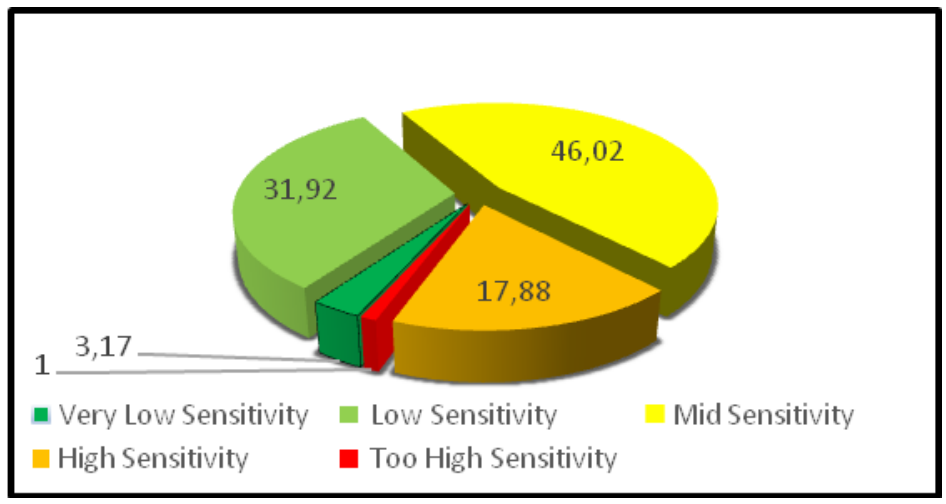

Figure 12: Spatial Distribution of Landslide Susceptibility Classes and Values of Babadağ District. 


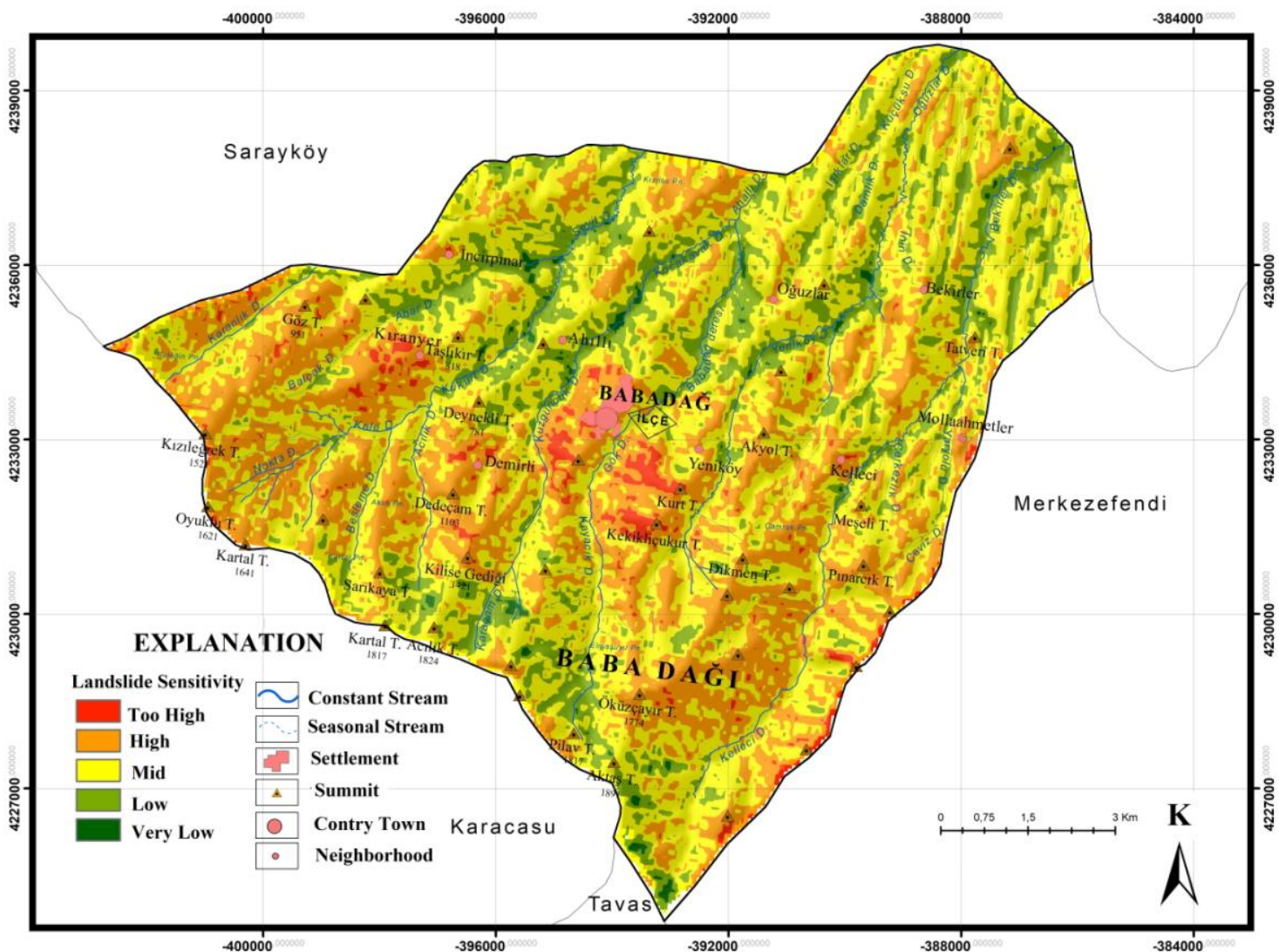

Figure 13: Landslide Sensitivity Map of Babadağ District.

When we evaluate Babadağ district center on a neighborhood basis, Yeniköy, Kelleci, Mollaahmet, Oğuzlar, Demirli, Kıranyer and İncirpınar have a "high degree of sensitivity", while Ahıllı has a "degree of medium sensitivity" (Chart 3).

Chart 3: Landslide Sensitivity Degrees of Settlement units in Babadağ District (Denizli).

\begin{tabular}{|c|c|c|c|c|c|}
\hline \multirow{2}{*}{$\begin{array}{c}\text { Neighborhood/Village } \\
\text { Name }\end{array}$} & \multicolumn{5}{|c|}{ Degree of Sensitivity } \\
\cline { 2 - 6 } & Too High & High & Mid & Low & Very Low \\
\hline Babadağ District Center & & $\mathrm{x}$ & & & \\
\hline Yeniköy & & $\mathrm{x}$ & & & \\
\hline Kelleci & & $\mathrm{x}$ & & & \\
\hline Mollaahmet & & $\mathrm{x}$ & & & \\
\hline Oğuzlar & & $\mathrm{x}$ & & & \\
\hline Demirli & & $\mathrm{x}$ & & & \\
\hline Bekirler & & $\mathrm{x}$ & & & \\
\hline Ahillı & & & $\mathrm{x}$ & & \\
\hline Kiranyer & & $\mathrm{x}$ & & & \\
\hline İncirpinar & & $\mathrm{x}$ & & & \\
\hline
\end{tabular}


Landslide-sensitive areas are where slope and precipitation are high and the bedrock consists of marn and clay stones. As a matter of fact, the sky triggers the landslide by carving the slopes formed by streams, marn and clay. Earthquakes, landslides, which can be triggered by the Babadağ fault in spring and winter seasons, where the Y network is high and long-lasting and accompanied by snow melts will trigger it. As a matter of fact, it is clear that the risk of landslides in the analysis is also high in areas close to fault lines.

\section{CONCLUSION}

12 factors that have an effect on the formation of landslides were analyzed with them in the formation of landslides by reference to land studies and evaluations obtained in the literature in Babadağ district of Denizli province. Analysis factors have been found to have different degrees of effects. Lithology, faults, slope and precipitation properties have been shown to have the most dominant effect on the formation of landslides in the field.

According to the analysis of landslide sensitivity with Analytic Hierarchy Process (AHP), 1\% $\left(1.23 \mathrm{~km}^{2}\right)$ of the total area of Babadağ districts very high, $17.88 \%\left(21.94 \mathrm{~km}^{2}\right)$ is high, $46.02 \%\left(56.47 \mathrm{~km}^{2}\right)$ medium, $31.92 \%\left(39.17 \mathrm{~km}^{2}\right)$ low, $3.17 \%\left(3.9 \mathrm{~km}^{2}\right)$ is in danger of landslides at very low sensitivity. A part of Babadağ district center, behind the high and fragmented topography is very high and high sensitivity.

Geomorphologically, landslide disaster risk areas are highly sloped slopes where the Upper Miocene and Pliocene erosion and filling flats rising with neotectonic movements are broken by streams. Likewise, the slopes formed by the lacustrine Upper Miocene-Pliocene claystone and marns, the slopes where the rivers are laterally eroded, sharp valleys and ridges. The claystone, marn, mudstone and sandstone units cut by normal faults parallel to each other with NW-SE strike highly sensitive to landslides. Therefore, precautions should be taken against the risk of landslides and earthquakes in the geomorphological units mentioned and to be built in these areas. Preventing landslides on slopes consisting of claystones and marnes, which are highly inclined due to defective topography, are not economical and always at risk of possible landslides.

\section{REFERENCES}

Akinci, H., Dogan, S., Kilicoglu, C., and Temiz, M. S. (2011). Production of Landslide Susceptibility Map of Samsun (Turkey) City Center by Using Frequency Ratio Method. International Journal of The Physical Sciences, 6(5), 1015-1025.

Althuwaynee, O. F., Pradhan, B. and Lee, S. (2012). Application of an evidential belief function model in landslide susceptibility mapping. Computers \& Geosciences, 44, 20-135.

Ayalew, L. and Yamagishi, H. (2005). The application of GIS-based logistic regression for landslide susceptibility mapping in the Kakuda-Yahiko Mountains, Central Japan. Geomorphology, 65, 15-31.

Bijukchhen, S. M., Kayastha, P., and Dhital, M. R. (2013). A comparative evaluation of heuristic and bivariate statistical modelling for landslide susceptibility mappings in Ghurmi-Dhad Khola, east Nepal. Arabian Journal of Geosciences, 6(8), 2727-2743.

Çellek, S., Bulut, F. and Ersoy, H. (2015). AHP Yöntemi'nin Heyelan Duyarlılık Haritalarının Üretilmesinde Kullanımı ve Uygulaması (Sinop ve Yakın Çevresi). Jeoloji Mühendisliği Dergisi, 39(2), 59-90.

Dağdeviren, M. and Eren, T. (2001). Tedarikçi Firma Seçiminde Analitik Hiyerarşi Prosesi ve 0-1 Hedef Programlama Yöntemlerinin Kullanılması. Gazi Üniversitesi Mühendislik Mimarlık Fakültesi Dergisi, 16(2), 41-52.

Dölek, İ. and Avcı, V. (2016). Çok Kriterli Karar Analizi Yöntemi (Çkay) Kullanılarak Arguvan (Malatya) ilçesi ve Yakın Çevresinde Heyelana Duyarlı Alanların Belirlenmesi. The Journal of Academic Social 
Sciences 33, 106-129.

Gokceoglu, C. (2016). Landslide Hazard Maps with Legislation, Powers and Scale Problematic. Ankara Ulusal Heyelan Sempozyumu Tebliğler içinde (s.1-3).

Gökçe, O., Özden, Ş. and Demir, A. (2008). Türkiye'de Afetlerin Mekansal ve İstatistiksel Dağılımı Afet Bilgileri Envanteri. Ankara: Bayındırlık ve Iskan Bakanlığ Afet Issleri Genel Müdürlügü.

Gökçeoğlu, C. and Ercanoğlu, M. (2001). Heyelan Duyarlılık Haritalarının Hazırlanmasında Kullanılan Parametrelere İlişkin Belirsizlikler. Hacettepe Üniversitesi Yerbilimleri Uygulama ve Araştırma Merkezi Bülteni, 23,189-206.

Kayastha, P., Dhital, M. R., and De Smedt, F. (2013). Evaluation of the consistency of landslide susceptibility mapping: a case study from the Kankai watershed in East Nepal. Landslides 10, 785-799.

Kumtepe, P., Nurlu, Y., Cengiz, T. and Sütçü, E. (2009, Kasım). Bolu Çevresinin Heyelan Duyarlılık Analizi. TMMOB Coğrafi Bilgi Sistemleri Kongresi, İzmir

Kwiesielewicz, M. and van Uden, E. (2004). Inconsistent and Contradictory Judgements In Pairwise Comparison Method in the AHP. Computers \& Operations Research, 31(5), 713-719.

Mater, B. (2004). Toprak Coğrafyası. İstanbul: Çantay Kitabevi.

Moradi, M., Bazyar, M. H. and Mohannadi, Z. (2012). GIS-Based Landslide Susceptibility Mapping by AHP Method, A Case Study, Dena City, Iran. Journal of Basic and Applied Scientific Research, 2(7), 6715-6723.

Nefeslioglu, H. A., Duman, T. Y. and Durmaz, S. (2008). Landslide susceptibility mapping for a part of tectonic Kelkit Valley (Eastern Black Sea region of Turkey). Geomorphology, 94(3-4),401-418.

Özdemir, M. A. (1996). Elazığ, Kurt Dere Vadisinde Tarımsal Arazilere Zarar Veren Heyelanlar. Fırat Üniversitesi Sosyal Bilimler Dergisi, 8(2), 195-208.

Özşahin, E. (2013). CBS Kullanılarak Hatay ili Heyelan Duyarlılık Analizi. Anadolu Doğa Bilimleri Dergisi, 4(1), 47-59.

Özşahin, E. (2014). Tekirdağ İlinde Coğrafi Bilgi Sistemleri ve Analitik Hiyerarşi Süreci Kullanarak Heyelan Duyarlılık Analizi. HUMANITAS - Uluslararası Sosyal Bilimler Dergisi, 2(3), 167-186.

Öztürk, D. and Batuk, F. (2007). Çok Sayıda Kriter ile Karar Vermede Kriter Ağırlıkları. Yıldız Teknik Üniversitesi Sigma Mühendislik ve Fen Bilimleri Dergisi, 25(1), 86-98.

Pektezel, H. (2015). Coğrafi Bilgi Sistemleri ve Analitik Hiyerarşi Yöntemi Kullanılarak Gelibolu Yarımadası'nda Heyelana Duyarlı Alanların Belirlenmesi. Turkish Studies - International Periodical for the Languages, Literature and History of Turkish or Turkic, 10(6), 789-814.

Saaty, T. L. and Vargas, L. G. (2001). Models, Methods, Concepts and Applications of the Analytic Hierarchy Process. Boston, Kluwer Academic Publishers.

Saaty, T.L. (1994). How to Make a Decision: The Analytic Hierarchy Process. Interfaces, 24(6), 19-43.

Soeters, R., and van Westen, C. J. (1996). Slope instability recognition, analysis, and zonation. In A. K. Turner, $\mathcal{E}$ R. L. Schuster (Eds.) Landslides, investigation and mitigation (pp. 129-177), National Academy Press, Washington D.C.

Sunkar, M., and Avcı, V. (2016). Şepker Çayı Aşağı Havzası'nın (Adıyaman Batısı) Heyelan Duyarlılık Analizi. Firat Üniversitesi Sosyal Bilimler Dergisi, 26(2), 13-43.

Tombuş, F. E. (2005). Uzaktan Algılama ve Coğrafi Bilgi Sistemleri Kullanılarak Erozyon Risk Belirlenmesine Yeni Bir Yaklaşım, Çorum İli Örneği, Yayımlanmamış Yüksek Lisans Tezi. Anadolu Üniversitesi Fen Bilimleri Enstitüsü, Eskişehir.

Varnes, D. J. (1984). Landslide Hazard Zonation: A Review of Principles and Practices, Varnes and the International Association of Engineering Geology, Commission on Landslides and Other Mass Movements on Slopes. Paris: UNESCO.

Yalcin, A. (2008). GIS-based Landslide Susceptibility Mapping Using Analytic Hierarchy Process and bivariate statistics in Ardesen (Turkey): Comparisons of Results and Confirmations. CATENA, $72(1), 1-12$. 